\title{
Who would be a dean? A light-hearted look at the impossibility of the task
}

\author{
PHILIP RHODES
}

British Medical fournal, 1977, 1, 953-956

Who would be a dean of medicine ? The thought is prompted by reading a paper on "The Medical Deanship" by Robert J Glaser, who has suffered the pangs of office. The word comes from St Benedict. In founding the monastery of Monte Cassino in the 6th century, he divided the brotherhood into groups of 10 , over whom he set one-the dean. The dictionary gives derivations from doyen and the Greek "dekanos," meaning one set over 10 . Fowler says that dean and doyen were originally the same word but that dean is now reserved for academic and clerical officers and doyen for senior members of any community, especially the diplomatic corps. Nowadays some members of the decanal group might often wish that they had only 10 others to deal with, for the other thing in Glaser's reminiscences was a true story. A businessman in a committee dealing with many major problems then afflicting the Stanford University Medical School passed him a note which read "I have come to the conclusion that there is no way to do your job." Often it seems like that.

\section{An impossible job}

Within the academic medical fraternity there is normally reluctance to become a dean, for most recognise that the office carries duties and responsibilities that will hinder the personal

Faculty of Medicine, University of Adelaide, Adelaide, South Australia

PHILIP RHODES, FRCS, FRCOG, dean (now postgraduate dean-elect, University of Newcastle upon Tyne and director of postgraduate medicine, Northern Regional Health Authority) development of the flowers of academe. There will be little time left for research, reading, teaching, practice, and writing. There will be innumerable committees to attend and endless chores. No one in his right mind could possibly seek such a post, and yet there are always a few who do. Their motives may be hard to fathom and may possibly be as individual as they are. Naturally there are those very willing to look on deans as power-seekers or escapers from the rigours of academic life, politicians, contemptible committee men. There are many other ways to twist psychological diagnoses to suit the prejudices of the observer, especially if he feels he has been harshly treated or ignored in his pleas by the occupant of the dean's chair.

\section{NO POWER}

It is nowadays fashionable to write a job description for every post in an organisation. It is part of management theory, which is essentially applicable to business, where there is a line of authority running from the highest to the lowest in the organisation. This is a paradigm taken from the military hierarchy, but it certainly does not describe a medical faculty or medical school. The dean is elected by the faculty and is accountable to it and meets his electorate perhaps monthly. In addition he is also accountable to the governing body of his school (in London) and to the supreme academic and governing bodies of his university. It is from all these that he derives his authority, but there is nobody who will say exactly what that is. Moreover, he is given his authority without any power to exercise it, and this is where the difficulties lie. In the final analysis, power means the ability to direct money, manpower, and other resources into different areas of an enterprise. But, except in a very limited way, a dean cannot do this on his own initiative. He may have his own ideas, but before they can be put into effect, he has a long task of persuasion in front of him. He must persuade all those to whom he is accountable. Why on earth should he bother? 
The reason probably lies in an outmoded concept of duty, for astonishingly deans are normally very conscientious. The duties of a dean are ill-defined so he has to decide what they are for himself. But the democrats in the academic world need not worry too much about the possibility of him becoming a dictator, for they can and do check the dean at almost every turn.

The dean inherits his organisation, which is a series of little empires, each of which is usually, but not always, headed by a professor. Each department has staked out its territory, geographically and within the curriculum, and therefore financially, and will defend that space, those resources, and educational time like a tiger having its young threatened. Without marshalling all other departments against one, the dean cannot vary, either up or down, any of the facilities on which a department depends for its existence. About $70-80 \%$ of the cash inflow to a medical school, or any academic institution, goes on salaries and wages. No professor will see his staff reduced. The dean has no academic oversight of a department because he cannot claim expert knowledge in every subject. While being ferocious in defence of territory, the department will find itself up against weak-kneed aggressors, who fear that if they attack one of their number it might be their turn next. Under these circumstances it is hard to see how any academic progress is ever achieved. Perhaps, the cynics might say, it never is.

\section{OTHERS' ASPIRATIONS}

So without power, financially or academically, what does a dean do, and how does he do it ? He is given qualified moral authority at his election, because not all of his electorate nor the bodies to which he is accountable will believe that he is fully capable of doing the job as they see it. And each person sees the job of the dean in a different way. Each has different aspirations for himself, his subject, his department, the curriculum, the purposes of medical education, and the aims of the medical school. The dean cannot possibly satisfy all of the staff and students, and so is naturally seen by all as the embodiment of the limiting power on personal progress. $\mathrm{He}$ is therefore inevitably the generator of frustration, and, when the totality of this has built up in enough breasts, the faculty wants him out. So the successful dean, if there is any such person, is the one who can keep the level of frustration within acceptable bounds. If he does only this he is almost a miracle man.

Each person in a medical school naturally wants most of his own aspirations fulfilled. The fact that he has never defined exactly what these are does not usually deter him in the least from leaping to the defence of his emotional personal interests, when he thinks they may be under attack. And he scents trouble from a very long way off, which when raised from the zoological analogy to the sphere of psychiatry might very well appear to others as paranoia. But if that is the right thing to call it, this symptom-complex is very cleverly hidden under the guise of apparently carefully thought out reasons why no change should be made, when such has been sugested. Those who believe themselves to be scientists are particularly adept at this. Sometimes they will even preface their remarks with something like "Speaking as a scientist..." Also they are very prone to lard their arguments with references to the number n, probabilities, and obscure medical education papers, and if not sternly discouraged they tend to draw diagrams of overlapping circles.

There is an almost incredible arrogance about all academics, but particularly lawyers and scientists, in their belief that they know how to marshal evidence and deduce policies from it. They resent amateurs trespassing on their own professional ground but are ever willing to step in with a solution to everyone else's problems. There is no wonder that when they meet a clear-eyed, some might say cynical, dean their emotions are roused into frustrating irritation, occasionally mounting to anger, forgetting that such emotional involvement is frowned on as disruptive of academic and scientific ideals.

All is supposed to be subject to democratic debate in which the will of the majority will prevail after listening to the arguments, and those in the minority will acquiesce in what their wiser brethren have agreed. How such a jejune belief could come to be accepted by a group of otherwise intelligent persons is beyond comprehension. But that is the way in which medical schools are believed to be run.

\section{UNLEASHING A NEW IDEA}

In practice, of course, the dean has some power because everything is finally channelled through him. He has the power of superior information. It might easily be agreed that he does not use it properly or well, but at least he has it. So he knows fairly early who is disaffected and about what. It is at this point that the dean's judgment is first exercised. Although he may be an innovator himself, by bringing in ideas from outside the medical school, he is mainly concerned with being the primary responder, on behalf of the school, to stimuli arising from within his organisation. I believe that he should always try to respond positively. If someone, or a group, wants to try out an idea they should be encouraged to do so. If the action proposed is outrageous then the dean might try to water it down to something which has some chance of success. The essential task is to try to judge the strength of the thrust behind the new idea and estimate how the environment-that is, the remainder of the faculty-might react to it.

This is the point at which the job of being a dean becomes fascinating. It has some analogy with the exploratory laparotomy or a decision whether a new drug should be tried in a particular patient. The findings or the response will almost certainly not be entirely what was expected, but there is immense interest in finding out. The decision has to be how to unleash the new idea on the faculty. The way in which it is done is all-important. The wrong approach may serve only to bring on a confrontation. The right one may bring about some rebuff or even rejection, but at least the new notion will not be utterly scouted and may live to come up some other day. There is an oddity worth observing here: an idea might first be rejected and then come up again later but this time be supported by the very ones who were initially its major opponents. They have let the ideas seep into their minds and then regurgitate it as if it were their own. It is wise at this juncture to avoid saying, "I told you so some months ago," but simply to sit back and accept that your idea has been appropriated and be glad that at last it will bear some fruit, but you will get no credit for it.

\section{DIAGNOSING A FACULTY}

To make his judgments, so that he can be as helpful as possible to all who call upon him, the dean has to analyse his faculty. This is like making a diagnosis. He has to try to weigh the strengths and weaknesses of individual members, the departments, and the general standing of the subjects within the curriculum. As with a diagnosis, much has to be left out of account simply so that you can get on with the job. If you wait for all the evidence then nothing will ever be done. Some members of the faculty, however, always do call for caution and for a little more time to collect the evidence and consider it further. These are the despair of a practical dean, for this argument nearly always finds some favour with academics. They feel safer in the libraries and laboratories and hope that the methods they use there will also be effective in running a human institution. Sometimes they are right, but by no means always.

It takes time to know your own medical school. The information about it comes in all the time, from the people popping in for a chat, from those with axes to grind, from conversations in the corridors and over lunch, in outpatient sessions with students, and in a whole variety of formal and informal occasions. Fortunately nobody can resist telling a dean what he thinks is wrong with the institution, whatever and wherever the dean 
might be. This is to be welcomed and not discouraged. But if a specific proposition is made by anyone, as distinct from vague bumblings, then it is wise for the dean to insist that it should be put in writing to him. This immediately gauges the intensity of feeling on the matter which the proposer has and has the immense merit that it makes him think harder about what he wants. The discipline of formulating exactly what he thinks is the first stage in a useful dialogue. The dean who acts on gossip and ill-defined notions, even though they emanate from senior and powerful people, is storing up trouble for himself and the school. If he gives way to this, which at first seems easiest, he can be pushed this way and that, seems to act in an arbitrary fashion, and is subject to all the drawbacks of the cabal. This informal unseen focus of power generates, quite rightly, more anger in those outside it than almost anything else. They can guess who is wielding the power which shapes their destinies, but cannot pin it down and do not know how to influence it.

This is the best argument for a written formal organisation structure, which is such anathema to very many members of the faculty. They recall how much better it was when they could just pick up the telephone and get some action. The formal organisation generates immense amounts of paper, which they feel they have to wade through. The administrative staff increases beyond all reasonable bounds and takes away much needed money from research and teaching. They have to spend an increasing amount of time on committee work. The debate is a very familiar one, and properly attracts a great deal of sympathy.

\section{AN OPEN SOCIETY}

What is forgotten by the critics of the formal structure of organisation is that only a few powerful ones could get action by telephoning the dean, and many of the faculty members did not have this easy access to him. Also, only they were privy to what in fact was happening. The object of disseminating large amounts of paper is simply to see that information does not remain solely in the dean's head and office. And along with the committees this load of paper is the result of the desire for open governance, where everybody who wants to can follow any policy as it develops in the school. The choice is quite plain. It is between open or closed governance. Anything less than open governance, so that committee time, wodges of paper, and administrative staff may be reduced, demands, in its turn, immense trust in the dean. And trust is something that academic bodies of many kinds seem quite unable to give. Each member of the faculty is so sure that he knows the failures of the faculty and how to put them right and so sure that if he does not watch his colleagues like a hawk they will do him down that he is unwilling to trust anybody, and certainly not the dean. If any faculty, or other academic organisation, really wants to reduce the horrors, as it sees them, of formal organisation, the remedy is quite clear and lies in their hands. It is to surrender some of the pillars of academe and move to a much more hierarchical line management system, such as is seen in armies. This, of course, is not being advocated here, but it is more than time that the alternatives were faced and their implications accepted with rather better grace than they have been.

\section{COMMITTEES}

Committee work is an unadulterated chore to many, but to others is a somewhat mitigated pleasure. Sometimes there is the feeling of being a member of a smooth working team, and that has its own delights. Even when there are recalcitrant members there can be interest in attempting to diagnose why they cannot accept certain arguments and in trying to accommodate to their difficulties. Fortunately most academics are not normally hardened in total opposition to reasonable ideas, so that there are always some grounds for hope. Moreover, committees can be educative in bringing to light objections to policies which had not been foreseen or understood. Committees are a very valuable source of information to a dean, and so are not to be despised.

The distribution of paper in large quantities need not waste much of an individual's time. He has the choice whether to read it or not. It is a decision taken daily about reading-matter in his ordinary working life, and there seems to be no reason why he should not exercise it here too. If he is prepared to trust the dean and his helpers he even has the choice of telling the administrators that he does not wish to receive any of the documents sent out. It needs only a decision about whether one will take part in the administration of the faculty or not, but that needs some strength of mind. In general, members of the faculty are unconscionably curious about what is being done in their name and cannot bear to think that they have not had a hand in it. They then read faculty documents as a sop to their own consciences and complain that they feel impelled to do it.

The finicky reader of documents is as much a bane to the dean as he who lights on a single item of interest to him alone. The pernickety act as barrack-room lawyers and want words and phrases changed. Most minutes are not legal documents and only very rarely does anybody want to read them again. The isolated topic man is usually one who has not bothered to find out what led up to it and was not interested in it until he thought he could make life difficult for someone else. He is a sporadic attender of meetings and a butterfly reader of minutes, but he feels he must make himself felt every now and then. In both these cases the perpetrators are not prepared to do any work for themselves. They just want to generate it for others, and in this they usually include the dean. The isolated topic chap often wants another committee set up to investigate it but will not serve himself because he is much too busy.

\section{POPPING IN}

Another scourge is he who just thinks he will pop into the dean's office to have a chat because he has had or has heard of a very good idea, and he thought the dean should know of it, for it sounded extremely interesting. He has not thought about it much himself and he does not want to do any further work on it, but he hopes that the dean might. He has to be thanked for his interest and time has to be spent on him, but it is hoped that when he leaves the office nothing will be heard of the matter again.

Despite these quirks of individual colleagues they are viewed with a tolerant and beneficent eye. With few exceptions they are pleasant people, who are intelligent and articulate. They each have their worth, and though somewhat wayward they are part of the team that has to be harnessed to the major aims of the medical school. There is pleasure in observing their individual actions, and in seeing how these are modified when they are joined together in groups, for often they are like chameleons in committee, and sometimes the apparent lamb can become a lion with claws to be feared by his colleagues in public. Without apparent inconsistency to himself he can be abrasive in committee and emollient to individuals whom he has attacked, afterwards. It is an amazing phenomenon, possible only to those who really believe that a person can be utterly divorced emotionally from a cause which he dearly espouses. This may be the ideal, but it does not accord with everyday observation.

There can be little wonder that the dean's job is impossible. By virtue of the academic system he has no control over his colleagues in the faculty, who will give authority to him only fitfully, often grudgingly, and in a way on which he can never rely. His only resources would seem to be information, persuasion, and some moral authority of varying degree. But to some irrepressible natures with rhinoceros hides, it can be fun.

\section{The outside face}

The dean might be thought of as facing inwards towards his school, trying to solve its problems with the least possible 
detriment to those concerned and estimating the strength of his rickety power base. From this he has to turn about and face the outside world as it impinges on his institution. The bodies which particularly affect it are his own school council (where that exists) the university as a whole, and those who wield authority in the health services. Not too uncommonly these have confused concepts of the interrelationships of medical practice, teaching, research, and administration, and how each reinforces and helps the other so that the overall care of patients and understanding of phenomena improves. None of these functions is fully independent of the others, yet health authorities may emphasise service, universities stress teaching and research, and both just tolerate administration, though they are far from sure that it is needed at all. Deans, of course, are those who do have reasonable concepts, but at least they are forced to take note of interconnectedness for it hits them every day.

By outside bodies the dean is assumed to be able to speak for his school with some authority. $\mathrm{He}$ is supposed to be able to interpret what its reactions will be to any new proposal. For the reasons presented here the dean is never quite so sure, but he has to act as if he were. The alternative is to refer everything back to his faculty so that he takes no decisions for the school at all. This may feed the ego of the faculty members, but also has the effect of diminishing the dean's standing, and therefore that of his school, outside and makes his power base in the faculty even more insecure. This is a right royal road to ruin. In pretending to know his faculty the dean runs risks. He knows that he will have to face his constituents sooner or later and persuade them that he has acted properly on their behalf. $\mathrm{He}$ can be caught 'twixt the devil and the deep sea. He is seen by the faculty as representing an outside body, and so alienates himself from his membership. If he fails to convince the faculty he has to face the wrath of the outside body for having misled them. In the words of John Donne, "He hath but a losing office."

A dean can be a leader of his faculty or its servant. The members of it are usually ambivalent about what they think he should be. Some want him always as a dogsbody to do their work for them. Others put him on pedestal, and there are all combinations of proportions of these two extremes. But few in the faculty have ever really given the concepts any thought at all, and most dither according to circumstance. When a dean is being elected, however, the faculty wants him to be a leader, hoping that this will absolve the members from doing chores that they claim distract them from doing their real work. It is only after a leader has been elected that many would wish to turn him into a servant. Of course, the dean has to be both, but when he wants to be a leader others want him to be a servant and vice versa.

\section{Personal}

So, who would be a dean? Well, I would. The job has as many fascinations as clinical medicine. Diagnosis in the setting of the faculty is at least as complex as at the bedside. Management, trying to get the best possible adjustment of the patient to his circumstances, is just as intriguing. The faculty has to be helped to adjust to its internal and external stresses and strains, self-generated sometimes, and at others imposed. There is pleasure in solving problems, even though no personal credit or approbation ensues. The faculty membership is usually less appreciative than one's patients, though even some of these are becoming more critical than formerly. As in other activities, there are moments of elation, despair, and self-pity, but medicine is for the service of others, and a dean certainly is involved in that.

There are compensations too for the relative loss of contact with patients. This is a reason given by many why they will not be candidates for the office of dean. The decision is hard at first, but in some sense clinical work can be seen as just boosting the ego, in the adulation of patients, staff, and students, and also of being a sphere within which one is relatively comfortable. To become a dean for the first time is certainly a casting off into potentially very rough waters and uncharted seas. Then comes a realisation of the possible value of the job in directly helping to foster education and research, which are the foundations of practice. And there is even the chance directly to influence the development of the health care services and make the administrative load on others lighter. The same spirit as before imbues the service, but it operates from a remoter point though its aims are the same. Perhaps the contribution ultimately to patient welfare is no less than that of those who remain in the wards, clinics, surgeries, and operating theatres. It may be only that one contribution is diffuse and difficult to define, whereas the other is specific and plain to see. It may also be that this is just rationalisation and justification after the event to preserve amour-propre in the dean.

\section{Conclusion}

A dean has an impossible task made both easy and difficult by faculty members and students: easy because they are nice people, and difficult because of their individuality. There is no hope whatever of reconciling their conflicting views on any and every subject, particularly those concerning their own particular medical school, on which all of them are willing to pontificate without end. The dean, however, is expected to effect reconciliation, also on any and every subject, while he suffers from the same disorders of partiality as his colleagues.

\section{Reference}

${ }^{1}$ Glaser, R J, Fournal of Medical Education, 1969, 44, 1115.

(Accepted 15 February 1977)
Systemic steroids should not be used. Topical betamethasone 17valerate in dimethyl sulphoxide, collodion, $50 \%$ isopropyl alcohol, ${ }^{1}$ and a cream base ${ }^{2}$ can induce partial repigmentation of areas of vitiligo. Similarly $0.05 \%$ clobetasol propionate in a cream base ${ }^{3}$ produced some repigmentation in half the patients (mostly Caucasians) who applied it twice daily to vitiliginous areas. As with psoralen treatment of vitiligo, the response in darker-skinned Asians and Africans may be more impressive than that in fair-skinned Caucasians. Unfortunately $0.1 \%$ betamethasone 17 -valerate and $0.05 \%$ clobetasol propionate will, if applied over a prolonged period, produce atrophy of both the epidermis and dermis. This makes their use on facial skin, where steroid rosacea and pustules may also be produced, particularly unwise. Personal experience, and talks with doctors who have treated vitiligo with local steroids make me sceptical of their use. For darkskinned patients I consider psoralen treatment as the best of a poor lot but, if it does not help, it might be worth trying the twice daily application of $0.1 \%$ betamethasone 17 -valerate in $50 \%$ isopropyl alcohol (Betnovate Scalp Application) for up to four months.

1 Kandil, E, British fournal of Dermatology, 1974, 91, 457.

2 Bleehen, S, Hritish fournal of Dermatology, 1976, 94, suppl, 1243. 